\title{
Metaxenia in apples cv. 'Rewena', 'Relinda', 'Baujade' as influenced by scab resistant pollinizers
}

\author{
Bodor, P. ${ }^{1}$, Gaál, M. ${ }^{2} \&$ Tóth, M. ${ }^{1}$ \\ ${ }^{I}$ Department of Pomology, Faculty of Horticultural Science, Corvinus University of Budapest, \\ H-1118 Budapest, Villányi út 29-43. \\ ${ }^{2}$ Department of Mathematics and Informatics, Faculty of Horticultural Science, Corvinus University of Budapest, \\ H-1118 Budapest, Villányi út 29-43.
}

Summary: Fruit quality of cross pollinated apples (Malus Xdomestica) influenced by the metaxenic pollen effect of the pollinizer was observed in Hungary. Flowers of three resistant cultivars ('Baujade', 'Relinda', 'Rewena') were hand pollinated with other resistant apple cultivars. Fruits were harvested on 25 September, 2005. Fruit quality was investigated in the laboratory of the Department of Pomology; Corvinus University of Budapest. Not only size and morphological parameters (diameter, height, stem length), but also refraction and acidic content of the fruits were measured.

According to the statistical analysis significant differences were determined on fruits among the groups as an effect of the pollen provider. In consideration of size parameters (diameter, height, weight) of 'Rewena' fruits pollination partner 'Freedom' and 'Prima' caused outstanding results but 'Florina' caused flatter fruits. Pollen of 'Florina' and 'Freedor:' caused a higher percent refraction in the fruits of 'Rewena'. In the case of 'Baujade' fruits 'Reglindis' - among cultivars we used as pollinizer - caused the biggest fruits medium flesh firmness and harmonic inner content values. 'Rajka' caused on one hand smaller fruits and on the other hand higher flesh firmness and inner content values in the case of 'Relinda' fruits. According to our data measured pollinizers varied the stem length as well.

Key words: Malus $X$ domestica, fruit color, fruit set, fruit size, seed number, stem length

\section{Introduction}

Apple cultivars are considered practically self incompatible that is why cross pollination is essential. When planting an orchard and choosing a pollination partner not only primary aspects (blooming time, compatibility, agroand phytotechnic demands, date of maturity) should be taken into consideration but also the occasional metaxenic effects which occur in a significant level in some years in Hungary. Phenomenon metaxenia has been known for a long while and it means the effects of the pollen provider expressed on the fruit of the pollinated cultivar.

Term xenia was first described more than 100 years ago by Focke (1881) in his article titled "The plant mixture" (original title: Die Pflanzen-Mischlinge). He defined two forms of xenia: the formal and coloration changes of the fruits. 125 years have passed since Focke's observation, and many other scientists have examined the phenomenon, moreover term metaxenia was also formulated and different definitions were created for the two terms. The explanation of pollen effects to the maternal tissues of the fruits is much more difficult than in the case of parts developed by cell fusion. The causes evoking metaxenia are still not known.

Swingle (1928) supposes that the hormones produced by the seeds are the responsible for it.
The existence of the phenomenon is proved by numerous scientists e.g. Bach (1928), Husz (1942) and Nebel (1930). On the other hand Höstermann (1924), Krumbholz (1932), Muth and Voigt (1928) decline its role. Tufts \& Hansen (1933) and Church \& Williams (1983) have not found metaxenic effects. Nyéki et al. (1980) and Kozma et al. (2003) have also analysed the economical effects of the phenomenon in the cultivation.

In our previous experiment (Tóth et al. 2005) flowers of five apple cultivars ('Golden Reinders', 'Regal Prince', 'Rewena', 'Renora', 'Idared') were hand pollinated with pollen of some new and traditional cultivars.

\section{Materials and methods}

Our experiment was set up at the research station of Faculty of Horticultural Science; Corvinus University of Budapest. The orchard was planted on rootstock M9 in 1999. It is irrigated and trained to slender spindle. The hand pollination was prepared at approximately on 3000 flowers of 'Rewena', Baujade' and 'Relinda' in 2005. Two flowers in a cluster were pollinated. Pollen of resistant cultivars was used (Table 1). In order to investigate the compatibility of combinations fruit set was investigated three times, and the number of viable and deaf seeds were also counted (Table 1). 
Table 1 Cross combinations, fruit set, average seed number

\begin{tabular}{|c|c|c|c|c|c|c|c|c|c|c|}
\hline \multirow[t]{2}{*}{ Code } & \multirow{2}{*}{$\begin{array}{l}\text { Parentage } \\
(q \times \delta)\end{array}$} & \multirow{2}{*}{$\begin{array}{c}\text { Flowers } \\
\text { crossed } \\
\text { (piece) } \\
04.30 . \\
2005 .\end{array}$} & \multicolumn{2}{|c|}{$\begin{array}{c}\text { Fruit set } \\
08.06 .2005\end{array}$} & \multicolumn{2}{|c|}{$\begin{array}{c}\text { Fruit set } \\
19.07 .2005\end{array}$} & \multicolumn{2}{|c|}{$\begin{array}{c}\text { Fruits } \\
\text { harvested } \\
25.09 .2005\end{array}$} & \multicolumn{2}{|c|}{$\begin{array}{l}\text { Average seed } \\
\text { number } \\
\text { (piece/fruit) }\end{array}$} \\
\hline & & & (piece) & $(\%)$ & (piece) & $(\%)$ & (piece) & $(\%)$ & viable & deaf \\
\hline 11 & Rewena $x$ Florina & 121 & 91 & 75.21 & 76 & 62.81 & 75 & 61.98 & 7.49 & 0.94 \\
\hline 12 & Rewena $\mathrm{x}$ Freedom & 107 & 63 & 58.88 & 38 & 35.51 & 35 & 32.71 & 3.97 & 0.06 \\
\hline 13 & Rewena x Prima & 99 & 75 & 75.76 & 53 & 53.54 & 46 & 46.46 & 7.24 & 0.48 \\
\hline 14 & Rewena x Reka & 121 & 92 & 76.03 & 69 & 57.02 & 60 & 49.59 & 7.00 & 0.68 \\
\hline 15 & Rewena $\mathrm{x}$ Reglindis & 96 & 79 & 82.29 & 47 & 48.96 & 45 & 46.88 & 7.35 & 0.29 \\
\hline 16 & Rewena $x$ Rajka & 99 & 61 & 61.62 & 46 & 46.46 & 38 & 38.38 & 7.79 & 0.71 \\
\hline$\$ 2$ & Baujade x Freedom & 108 & 48 & 44.44 & 39 & 36.11 & 39 & 36.11 & 11.33 & 0.13 \\
\hline 54 & Baujade x Reka & 88 & s9 & 67.05 & 59 & 67.05 & 53 & 60.23 & 11.81 & 0.17 \\
\hline 55 & Baujade $x$ Reglindis & 87 & 52 & 59.77 & 29 & 33.33 & 29 & 33.33 & 10.79 & 0.52 \\
\hline 102 & Relinda $\times$ Freedom & 103 & 25 & 24.27 & 22 & 21.36 & 20 & 19.42 & 7.47 & 0.16 \\
\hline 106 & Relinda $\times$ Rajka & 100 & 41 & 41.00 & 36 & 36.00 & 23 & 23.00 & 8.65 & 0.09 \\
\hline
\end{tabular}

combinations and very good in other combinations according to Wertheim et al. (1996). The relative high fruit set ratio may be attributed to the fact that 2 flowers per cluster were pollinated. De Witte et al. (1996) observed similar result in their experiment when crossing non resistant cultivars. However they measured lower seed number in most combinations. The resistant cultivars in our experiment produced 7-8 seeds per fruit in most combinations; moreover 'Baujade' fruits produced over 10 seeds per fruit. Low seed number

The fruits of all combination were harvested in 25 September 2005. Up to the investigations carried out in the laboratory of the Department of Fruit Science the samples were kept in cold storage.

Diameter and height of fruits were measured with Mitutoyo CD-15DC type caliper (connected to pc) with millimeter accuracy. The weight of the fruits was measured with Type KPZ-2-05-4/6000 scale. Magness-Taylor penetrometer with $11.1 \mathrm{~mm}$ probe was used for flesh firmness measurement. The measurement was carried out at the longest outline of the fruits in opposite sides (the welland less-coloured so the sun exposed and shaded side). Flesh firmness was expressed in $\mathrm{kg} \mathrm{cm}^{-2}$.

Refraction was measured from homogenous filtered juice reached with fruit-press. ATAGO Palette PR-101 type refractometer was used and the results were expressed in Brix\% (g 100g $\mathrm{g}^{\mathrm{l}}$ ). SCOTT TitroLine 96 semi automatic titrometer was used to determine the titratable acidic content of the fruits with the help of the following formula:

Acidic content $(\%)=\mathrm{NaOH}$ consumption $\left(\mathrm{cm}^{3}\right) \times \mathrm{NaOH}$ factor $\times$ malic acid equivalent $\times$ dilution / sample $\left(\mathrm{cm}^{3}\right) \times 100$.

Analysis of Variance was used for 'Baujade' and 'Rewena' combinations as the sample sizes were large enough and the data followed normal distribution. In the case of equal variances

Sheffe test were taken into consideration. In some combinations sample size was not large enough and the standard deviations were also different. In these cases KruskallWallis test was used from nonparametric tests for comparing all combinations belonging to the same mother cultivar and for creating groups. More precise result was reached when using Mann-Whitney pair-wise comparison. In some cases the results could be determined evidently from the graphs. No statistical analysis was carried out in the case of these parameters.

\section{Results and discussion}

Satisfying data were measured in all combinations in the case of fruit set. Fruit set was good in the case of 'Relinda' in combination 'Rewena' $\times$ 'Freedom' refers to compatibility problems, although it is not supported by the previous results published in the topic of S-allele investigation (Nerum \& Keulemans 2004; Sakurai et al. 2000).

Metaxenic effect to fruit size was previously justified; fruit size reducing effect was proved in the case of Malus sp. (Tóth et al. 1985) and smaller sized cultivars (Keulemans et al. 1996). With our present results we would like to emphasize the quality enhancing attribute of metaxenia.

Differences of 'Baujade' fruit diameters influenced by different pollinizers are shown in a box plot (Figure I). According to statistical analysis the originally bigger fruited 'Freedom' caused significantly smaller fruits than 'Reka' (average: $69.30 \mathrm{~mm}$ ) or 'Reglindis' $(71.58 \mathrm{~mm})$. On the other hand in the case of 'Rewena' fruits 'Freedom' as pollinizer caused the biggest fruits. 'Prima' resulted fruits over 65 millimetre diameter as well. Other pollinizers resulted 60-65 millimetre diameter fruits. Scheffe-test also supports this result as it divided cultivars into two groups in the same way (Table 2).

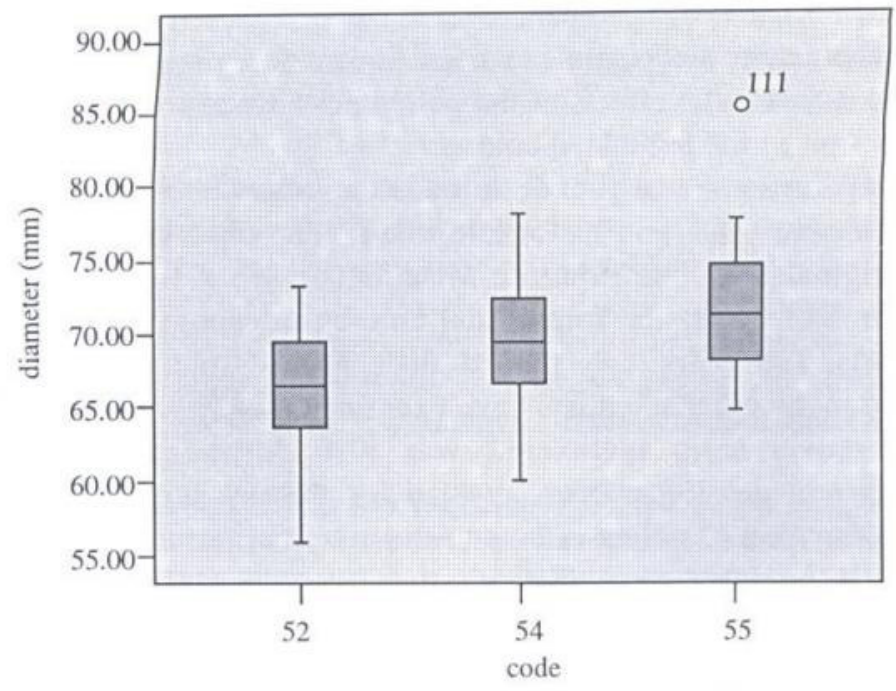

Figure 1 Diameter of 'Baujade' fruits; influenced by 'Freedom' (52), 'Reka' (54) and 'Reglindis' (55) pollinizers 
In the case of 'Relinda' fruits, no statistical analysis was needed to prove that 'Freedom' resulted significantly bigger fruits $(66.26$ $\mathrm{mm}$ in average) than the middle sized 'Rajka' $(56.98 \mathrm{~mm}$ in average); so similar effects were observed as in the case of 'Rewena' fruits.

Among cultivars involved in our experiment as pollinizer, 'Freedom' has the biggest fruit size, followed by 'Florina'. The other cultivars are considered as medium fruit sized cultivars (Tóth 2001). 'Freedom' pollinizer resulted in approximately $66 \mathrm{~mm}$ diameter fruits in the case of all three mother cultivars. This value is higher than in other combinations of 'Relinda' and 'Rewena' fruits, but lower than in combinations of 'Baujade' fruits. The phenomenon can be explained by the date of harvest. The optimal harvest dates in Hungary are the following for the three mother cultivars: end of September for 'Rewena', beginning of October for 'Relinda' and middle of October for 'Baujade'. So possibly the smaller fruit size of the 'Baujade' $\times$ 'Freedom' combination is the result of harvesting too early.

Similar evaluation was used regarding the fruit height, and in the case of 'Baujade' and 'Relinda' fruits, similar groups were created as in evaluation of fruit diameter. 'Freedom' and 'Prima' as pollinizer caused the highest fruit height in the case of 'Rewena' fruits and the fruit diameter was also the highest in these combinations. On the other hand the effect of the pollinizer manifested in the shape index (ratio of diameter and height) (Figure 2). As a result of this, values at approximately 1 were counted in the case of the originally elongated 'Rewena' fruits. Values around 1 refers to the fact that the fruits from crossings were approximately globular shaped. 'Rewena' fruits with a pollination partner of 'Florina' became rather flattened, while with 'Freedom' rather elongated. Fruit weight followed fruit size in all cross combinations of the three mother cultivars.

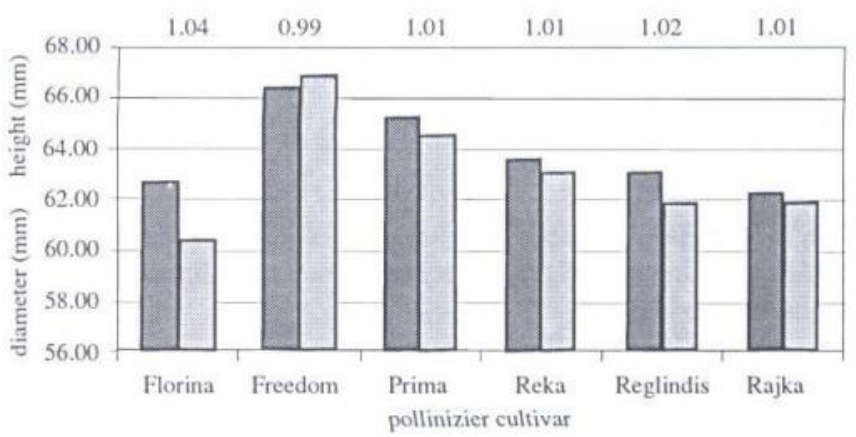

diameter $(\mathrm{mm})$ Dheight $(\mathrm{mm})$

Figure 2 Diameter, height and shape index (at column tops) of 'Rewena' fruits; influenced by different pollinizers
We would like to introduce stem length results in Rewena' fruits as 'Rewena' fruits have the longest stem. Two groups were created according to the Scheffe-test (Table 2). 'Florina' and 'Freedom' resulted the longest stems while 'Reglindis' and 'Rajka' caused the shortest stems. Regarding stem length, we found comparable results in our previous work (Tóth et al. 2005). It is a fact that too short stem causes fruit drop before harvest. In some cases the stem elongating effect could be useful as a result of pollination with a longer stemmed cultivar. It is reasonable to measure stem length and stem cavity depth together in further experiments as the section of the stem beyond the stem cavity helps the fruit to stay on the tree.

Regarding to flesh firmness three groups $(<6 ; 6-6,5 ; 6,5<$ $\mathrm{kg} \mathrm{cm}^{-2}$ ) were created according to statistical analysis in the case of 'Rewena' fruits. The least flesh firmness was measured in the case of 'Reka' pollinizer, while 'Reglindis' and 'Rajka' produced the highest values. The groups are illustrated in a box plot (Figure 3). We measured medium flesh firmness values in the case of bigger fruited combinations while smaller fruited combinations showed higher values. Only a two-decimal difference was measured between the two 'Relinda'

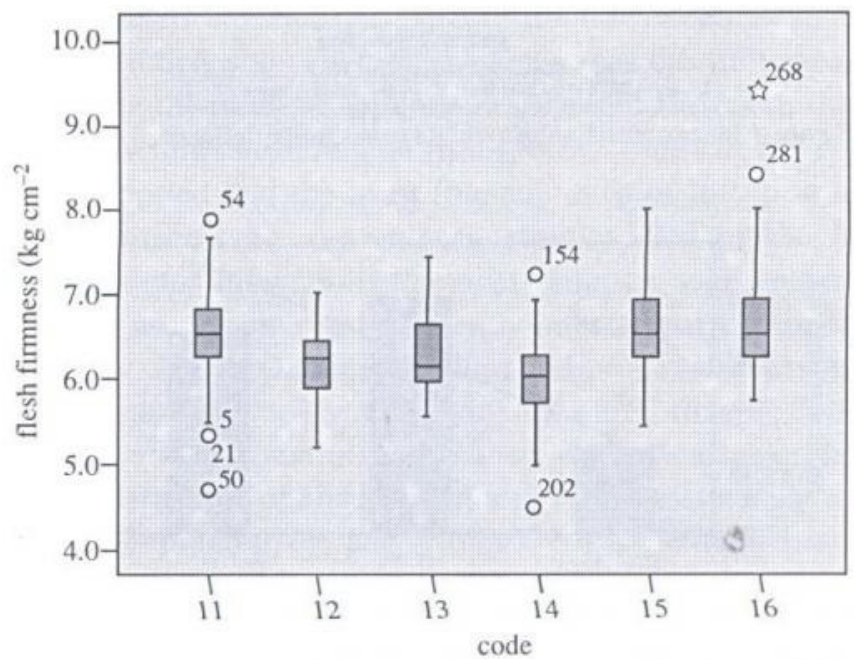

Figure 3 Flesh firmness of 'Rewena' fruits as influenced by 'Florina' (11), 'Freedom' (12), 'Prima' (13), 'Reka' (14), 'Reglindis' (15) and 'Rajka' (16) pollinizers. 
combinations and it was not considered as a significant difference according to the Mann-Whitney test. 'Freedom' pollinizer resulted in the highest value in the case of 'Baujade' fruits while the other two combinations came out at approximately $1 \mathrm{~kg} \mathrm{~cm}^{-2}$ lower values.

Flesh firmness is also such an attribute which can not be measured in an absolute scale as it decreases the taste quality beyond a certain value. On the other hand previously published results mention only exact values. Putter et al. (1996) did not observe differences among combinations of the same mother cultivar. Effect on flesh firmness influenced by different pollinizers is considered as a metaxenic effect by Kovács (1976). 'Reka' resulted in the lowest flesh firmness value in our experiment, similarly to our previous investigation (Tótin et al. 2005).

Refraction and acidic content were measured among inner content values. Three groups were created according to our experiment (refraction: $11.50-12.50 ; 12.50-13.50$ and $13.50-14.50 \%)$. 'Freedom' and 'Florina' pollinizers produced the highest refraction values in the case of 'Rewena' fruits while 'Reka' and 'Rajka' resulted the lowest values (Figure 4). Contradictory results were measured in the case of 'Baujade' (Figure 5) and 'Relinda' fruits. In the case of these cultivars 'Freedom' pollinizer resulted the lowest refraction and acidic content while 'Reka' resulted the highest refraction. According to the contradictory results pollinizer effect can not be justified in the case of inner content values. Consistently lower values resulted from

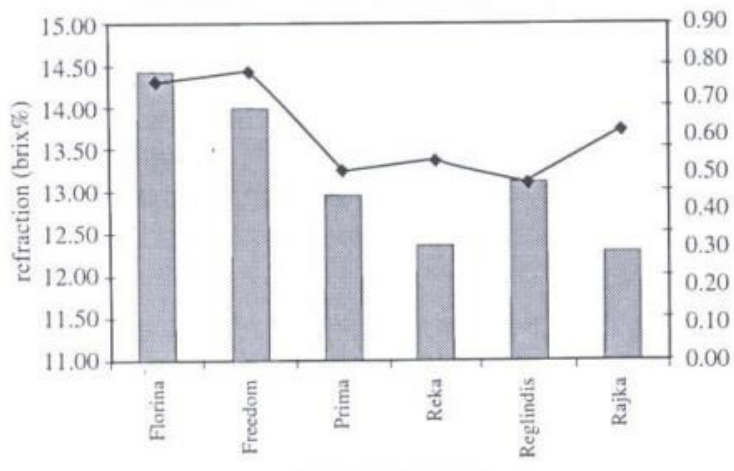

polleinizer cultivas

refraction (Brix \%) $\rightarrow$ acidic content (\%)

Figure 4 Inner content values of 'Rewena' fruits; influenced by different pollinizers

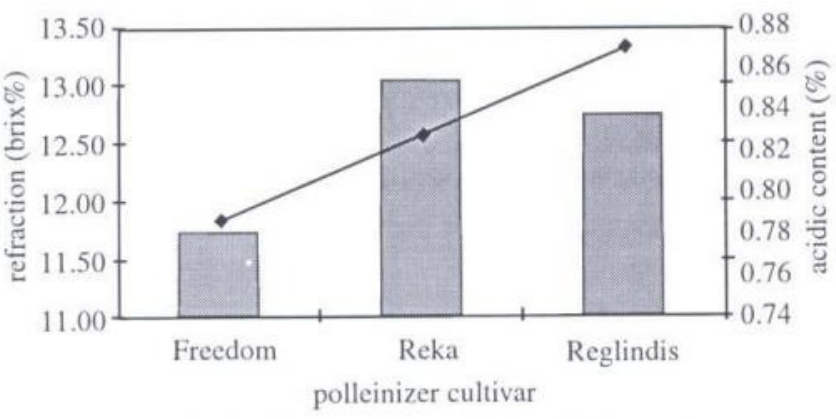

refraction (Brix\%) $\longrightarrow$ acidic content $(\%)$

Figure 5 Inner content values of 'Baujade' fruits; influenced by different pollinizers cultivar 'Reka' both in our present and previous experiment (Tóth et al. 2005). Putter et al. (1996) did not find differences among combinations of the same mother cultivar according to these parameters, either.

\section{References}

Bach, F. (1928): Über die künstliche Kreuzung einiger wichtiger Apfelsorten. Gartenbauwiss. 1: 358-374.

Church, M.R. \& Williams, R.R. (1983): Comparison of the compatibility and metaxenia effects of several dessert apple and ornamental Malus cultivars with Cox's Orange Pippin. J. of Hort. Sci. 3: 343-347.

De Witte, K., Vercammen, J., Daale, G. van \& Keulemans, J. (1996): Fruit set, seed set and fruit weight in apple as influenced by emasculation, self-pollination and cross-pollination. Acta Hort. 423: 77-183.

Focke, W.O. (1881): Die Pflanzen-Mischlinge: ein Beitrag zur Biologie der Gewäsche. Borntraeger, Berlin.

Höstermann, I. (1924): Zur Trage der Xenienbildung gärtnerischen Kulturpflanzen. Angew. Bot. 6: 232-242.

Husz, B. (1942): Zur Frage der Apfelxenien. Magyar Királyi Kertészeti Akadémia Közleményei. 8: 128-133.

Kovács, S. (1976): Results of experiments on metaxenia in apple. Kertészeti Egyetem Közleményei. 40: 155-163.

Kozma, P., Nyéki, J., Soltész, M. \& Szabó, Z. (2003): Floral Biology, pollination and fertilisation in temperature zone fruit species and grape. Akadémiai Kiadó, Budapest.

Keulemans, J., Brusselle, A., Eyssen, R., Vercammen, J. \& Daele G van (1996): Fruit weight in apple as influenced by seed number and pollinizer. Acta. Hort. 423: 201-210.

Krumbholz, G, (1932): Untersuchungen über das Vorkommen von Xenien und Metaxenien bei Äpfeln. Gartenbauwiss. 6: 404-424.

Muth, F. \& Voigt, G. (1928): Untersuchungen über Xenien. Ber. Lehranst. Gesen.

Nebel, F. (1930): Xenia and Metaxenia in apples. N. Y. State Agr. Expt. Bull. 170: 1-16.

Nerum, I. \& Keulemans, J. (2004): Update on and Review of the Incompatibility (S-) Genotypes of Apple Cultivars. HortScience. 39: 943-947.

Nyéki, J. (1980): Xénia és metaxénia. In: Nyéki J. (ed.) Gyümölcsfajták virágzásbiológiája és termékenyülése. Mezôgazdasági Kiadó, Budapest. pp 72-74.

Putter, H., Kemp, H. \& Jager, A. (1996): Influence of pollinizer on fruit characteristics of apple. Acta Hort. 423: 211-218.

Sakurai, K., Brown, S.K. \& Weeden, N.F. (2000): Selfincompatibility alleles of apple cultivars and advanced selections. HortScience. 35: 116-119.

Swingle, W.T. (1928): Metaxenia in date palm, possibly a hormone action by the embryo or the endosperm. J. Hered. 19: 257-268.

Tóth, M. (2001): Gyümölcsészet (Pomology). 2nd edition. Primom Kiadó, Nyíregyháza

Tóth, M., Dula, P., Tóth, F., Soltész, M. \& Nyéki, J. (1985): Effect of Malus pollinators on the quality of apple. Acta Agron. Acad. Sci. Hungaricae. 34: 72-76.

Tóth, M., Gaál, M. \& Bodor, P. (2005): Metaxenic pollen effect of scab resistant apple cultivars on the fruit of apple. Int. J. of Hort. Sci. $11(3): 47-52$.

Tufts, W.P. \& Hansen, C.T. (1933): Xenia and metaxenia in the Bartlett pear. Proc. Amer. Soc. Hort. Sci. 30: 134-139.

Wertheim, S.J. (1996): Methods for cross pollination and flowering assessment and their interpretation. Acta Hort. 423: 237-241. 